Pak. j. sci. ind. res. Ser. B: biol. sci. 2019 62B(1) 49-57

\title{
Assessment of Water Quality Parameters and their Impact on Distribution of Fish Fauna in River Neelum, Azad Jammu \&Kashmir, Pakistan
}

\author{
Sakhi-uz-Zaman ${ }^{\text {ab }}$, Nuzhat Shafi ${ }^{a}$, Usman Ali ${ }^{\mathrm{c} *}$ and Huma Ayub \\ ${ }^{a}$ Department of Zoology, University of Azad Jammu \& Kashmir, Muzaffarabad, Pakistan \\ ${ }^{b}$ Wildlife and Fisheries Department, Government of Azad Jammu \& Kashmir, Muzaffarabad, Pakistan \\ ${ }^{c}$ Department of Zoology, Mirpur University of Science and Technology (MUST), Mirpur-10250, Pakistan
}

(received September 19, 2017; revised July 28, 2018; accepted August 1, 2018)

\begin{abstract}
Present study deals with the fish distribution in River Neelum and measures the effect of physicochemical parameters on fish distribution. Temperature, $\mathrm{pH}, \mathrm{DO}$, hardness, alkalinity, and electric conductivity, total dissolved solids, chloride, nitrite, nitrate and sulphate were analyzed from different tributaries and their mixing point with River Neelum. All the parameters were in the range of guideline values set for surface water by WHO. A total 8 fish species including Oncorhynchus mykiss, Salmo trutta fario, Glyptothorax kashmirensis, Triplophysa stoliczkai, Diptychs maculatus, Schizothorax plagiostomus, Triplophysa kashmirensis and Glyptosternum reticulatum were recorded in the six river sites during study period. Maximum (8) fish species were recorded at Saonar followed by Sharda and Taobutt (7 each), Yamgar (6) and Sangli (5), whereas the minimum fish diversity was noted at Shonter (4). Temperature showed a highly significant $(\mathrm{p}<0.01)$ correlation with fish distribution in the River Neelum. Sharda and Janawai tributaries identified the most suitable waters for fish farming. Results showed that AJ\&K is least polluted area. However circumstances may be changed in future due to the construction of dams on River Neelum in occupied Kashmir. At the completion of these dams, water flow will be decreased and pollutants will be concentrated in rest of the water. The level of pollution thence may exceed the WHO guidelines set for surface water. This baseline study can be used as a reference for future exploration.
\end{abstract}

Keywords: Neelum River, water quality, freshwater fish, pollution

\section{Introduction}

Water quality parameters such as turbidity, temperature, TSS, TDS, DO, COD, BOD and $\mathrm{pH}$ have significant effects on fish distribution and also determine the diversity and growth of the fish species. The quality of these parameters has been deteriorated due to sewage, urban, agricultural and industrial discharge in surface water (Cloramm, 2010; Sarkar et al., 2008; Barzani et al., 2007; Kamal et al., 2007; Emara et al., 1993).

Many watercourse ecosystems worldwide are distinguished by species replacement patterns along altitudinal gradients (Taniguchi and Nakano, 2000). Fish species richness decrease with headwaters, physicalchemical factors, barrier and high current velocity (Mendonca et al., 2005). Water temperature proved to be a critical element in distribution of freshwater fishes (Torgersen et al., 2001; Taniguchi and Nakano, 2000). Temperature increase is attributed to the global change and has produced an addition in mass deaths and a

*Author for correspondence;

E-mail: usman.zoology@must.edu.pk significant decline of the fishing stocks (Cussac et al., 2009).

The majority of the snow trout are limited to the TransHimalayan region of the Indus system where the temperature remains below $20{ }^{\circ} \mathrm{C}$ and only a small number comes down from the mountains, mostly due to low water temperature (Akhtar, 1991). Higher temperature enhances algal blooms, reduces the concentration of oxygen in water and increases the rate of organic matter degradation (Cussac et al., 2009). A universal effect in mountain rivers is urban discharge. Turbidity affects behavior and distribution of fish and reduced foraging ability (Minello, 1996; Barret et al., 1992) thus decrease in growth rate (Benfield and Minello, 1996; Gardner, 1981). Water pollution is brought about by inputs of organic effluents, which increases BOD, COD values and nutrient improvement, especially by ammonia and nitrates. Nutrient augmentation generally decreases macro-invertebrate richness (Ali et al., 2010; 1980; Miserendino et al., 2008), consequently affecting the fish distribution. 
Fish species richness increased with the catchment areas, river size and downstream (Rauf et al., 2009). Fish abundance increases along the river range, indicating that the habitat transportation capacity increases downstream. The water depth and rock surfaces become visible to be the main factors limiting the capability of a watercourse to supply refugees (Miserendino et al., 2008; Maitland, 2004). Water quality reflects the broad variety of necessary conditions fundamental to the catchments e.g. high and low ground, hard and soft rocks, rich and poor soils, high and low rainfall (Maitland, 2004). High concentration of suspended solids in rivers normally present as a result of land erosion, following deforestation etc. (Rauf et al., 2009; Siddiqui et al., 2008). Water current velocity, physicochemical factors and habitat differences played a vital role to influence the distribution of species (Mendonca et al., 2005; Maitland, 2004). During rainy season, steep streams resulted in torrential flow and many individuals are carried through and killed by the force of the current, predaceous fishes or the rise in salinity (Rivas, 1958).

Streams are subjected to extensive modification through human expansion worldwide (Miserendino et al., 2008; Siddiqui et al., 2008). Urbanization resulted in frequent disturbances to streams and its persistent effects reduced water quality and threaten aquatic biota (Miserendino et al., 2008; Mendonca et al., 2005), for the reason that biological communities vary in time and space, as a result of differences in habitat structure (Gorman and Karr, 1978), resource accessibility and biogeographical patterns (Grenouillet et al., 2002).

The River Neelum is the largest tributary of the Jhelum and receives a large number of tributaries itself. In summer, most of the inflowing streams are turbid and in flood. The river and some of its tributaries support fish stocking however, not much work in hand regarding fish stocking or rearing in this area. Due to inappropriate means of transportation, harsh weather condition and Line of Control (LOC) conflict between Pakistan and India, researchers, particularly from Pakistan and worldwide were not allowed to work in this area (Ali et al., 2007). Hence the majority of its wildlife, including fisheries could not attract much attention, consequently area remaining unexplored. Little study has been conducted on the water quality of River Neelum and its impact on fish distribution. The present study was aimed to investigate the physicochemical characteristics of River Neelum and their impact on fish distribution in remote areas of the upper Neelum Valley.

\section{Material and Methods}

Study Area. Neelum Valley is predominantly mountainous and hilly tract, with elevations ranging from $360 \mathrm{~m}$ in the south to $6,325 \mathrm{~m}$ in the north is one of the beautiful but remote and difficult to approach valleys of AJ\&K. The snowline in winter is around $1,200 \mathrm{~m}$ while in summer it rises to $3,300 \mathrm{~m}$. People are more dependent upon natural resources for their survival.

River Neelum is one of the main rivers flowing in the territory of Azad Jammu \& Kashmir. It enters in Azad Jammu \& Kashmir at Taobutt and falls into River Jhelum at Domel, Muzaffarabad after traveling about $200 \mathrm{~km}$ from its entrance in AJ\&K. Area of the present study starts from Sharda ( $34^{\circ} 47^{\prime} 46.26^{\prime \prime} \mathrm{N}, 74^{\circ} 11^{\prime} 27.12^{\prime \prime} \mathrm{E}$; $1860 \mathrm{~m}$ asl) and ends at Taobutt ( $34^{\circ} 43^{\prime} 28.87^{\prime \prime} \mathrm{N}, 74^{\circ}$ 42' 32.04" E; $2265 \mathrm{~m}$ asl), covering $75 \mathrm{~km}$ long strip of River Neelum. Monthly surveys were carried out between October, 2010 and September, 2011 for physicochemical analysis of water and fish distribution assessment. By using systematic sampling method, six river sites were chosen, started from Sharda, distant at $15 \mathrm{~km}$ from each other, ending up at Taobutt. Human settlement is recorded at both banks of the River Neelum. There is no provision of waste water treatment. Urban discharge poured in river without being treated and making it environmental friendly. Right bank of the river is more populated with comparatively less vegetation cover. Important plant species are Viburnum grandiflorum, Taxus baccata, Ephedra gerardiana, Angelica cyclocarpa, Pinus wallichiana, Cedrus deodara and Juglans regia etc. (Qamar et al., 2010).

Water sampling. On spot analysis and sampling was done at the middle of the day. Samples of water were collected using plastic bottles (rinsed by hydrochloric acid and then washed with distilled water). Bottles were filled from a gentle flow of water and the caps were replaced immediately (Ali, 2010). Samples were placed in a cooler having ice slurry in order to minimize chemical changes during transportation to laboratory at the Department of Zoology, Muzaffarabad for further analysis. Samples were transported to the laboratory as soon as possible, considering the shelf life of parameters.

The DO meter (Jenway, Model 970, England 2510) was used to measure dissolved oxygen at the spot 
analysis. Hardness was measured by using EDTA titrimetric method. Chloride concentration and alkalinity were measured by titration method (APHA, 2005). Concentration of nitrate was detected using ultraviolet spectrophotometer (CEUL, CE 2021) at $220 \mathrm{~nm}$ and $275 \mathrm{~nm}$ wavelengths. Similarly nitrite concentration was measured using spectrophotometer at $540 \mathrm{~nm}$ (APHA, 2005).

Chemical oxygen demand was determined by open reflux method (5220 B) (APHA, 2005), while biological oxygen demand was measured by using dilution method (5210 C) (APHA, 2005). Ammonia concentration was investigated using ammonia-selective electrode method (4500 D) (APHA, 2005). Sulphate concentration was determined by turbidimetric method using visible spectrophotometer (VIS 1100 BMS) at $420 \mathrm{~nm}$ wavelength (APHA, 2005).

$\mathrm{pH}$ of water samples measured on the spot by using $\mathrm{pH}$ meter (Weilheium, Model WTW 82362, Germany) (2550) (APHA, 2005). Likewise, temperature, electrical conductivity (EC) and turbidity were recorded directly in field using thermometer, EC meter (Eutach Instruments, Model 269351, Singapore) and turbidity meter (Lovibond, Model PCHQ 895, Germany), respectively.

Fish sampling. Fish samples were captured at study sites by using a variety of fishing devices including Spinners (Panther Martin, 2PMR-G) and nets (cast net, drag net, gillnet and hand net). Identification was made in the field with the help of field guide (Mirza, 1982). After identification, fish were released back to the river safely. Unidentified species were preserved in $10 \%$ formalin and brought to the limnology laboratory of the University of Azad Jammu \& Kashmir for identification.

Descriptive statistics was used to analyze gathered data by using Statix software (ver. 9.0) and MS Excel (ver. 2007) at the Department of Zoology, University of Azad Jammu \& Kashmir.

\section{Results and Discussion}

A total of 17 different physical and chemical water quality variables were estimated from 6 selected sites of River Neelum. These sites showed smaller variation in temperature which ranged between $7.08^{\circ} \mathrm{C}$ and 7.63 ${ }^{\circ} \mathrm{C}$ with the mean value of $7.34 \pm 0.08{ }^{\circ} \mathrm{C}$ (Table 1 ). Highest temperature was recorded at Halmat $\left(7.63{ }^{\circ} \mathrm{C}\right)$ followed by Sharda $\left(7.33 \pm 2.5^{\circ} \mathrm{C}\right)$, Kail Seri and Jander Seri $\left(7.25 \pm 2.1^{\circ} \mathrm{C}\right.$ each), and minimum at Shonter $\left(7.08 \pm 2.6^{\circ} \mathrm{C}\right)$ (Fig. 1). EC value of selected spots of River Neelum ranged between $151.50 \pm 11.1 \mu \mathrm{S} / \mathrm{cm}$ ) and $112.75 \pm 7.7 \mu \mathrm{S} / \mathrm{cm}$ with an average of $132.53 \pm$ $5.91 \mu \mathrm{S} / \mathrm{cm}$ (Table 1). The maximum value was recorded at Halmat $(151.50 \pm 11.1 \mu \mathrm{S} / \mathrm{cm})$, gradually decreasing to Shonter $(144.67+13.9 \mu \mathrm{S} / \mathrm{cm})$, Jander Seri $(137.0$ $\pm 12.9 \mu \mathrm{S} / \mathrm{cm})$ and Kail Seri $(112.75 \pm 7.7 \mu \mathrm{S} / \mathrm{cm})$

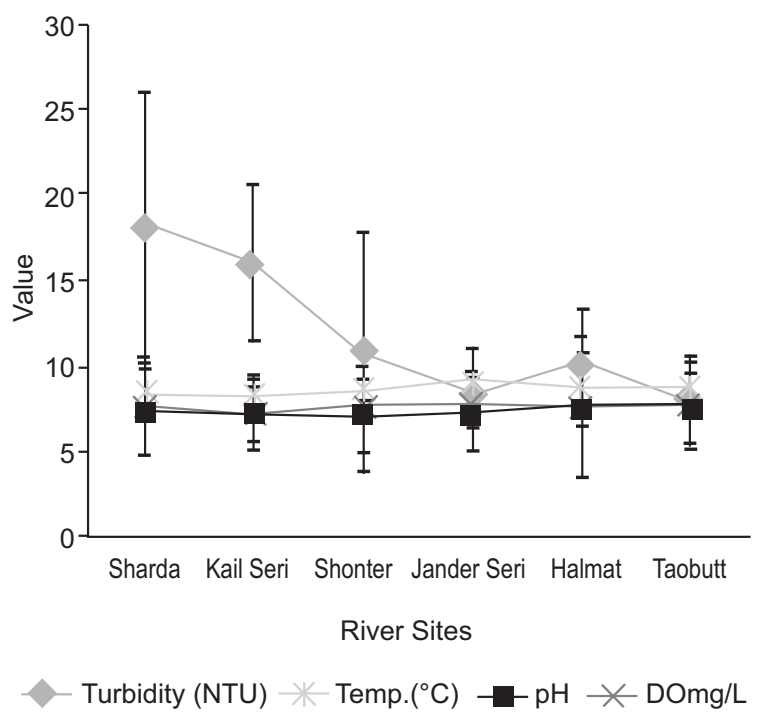

Fig. 1. Physical properties of selected sites of River Neelum in the study area during 2010-11.

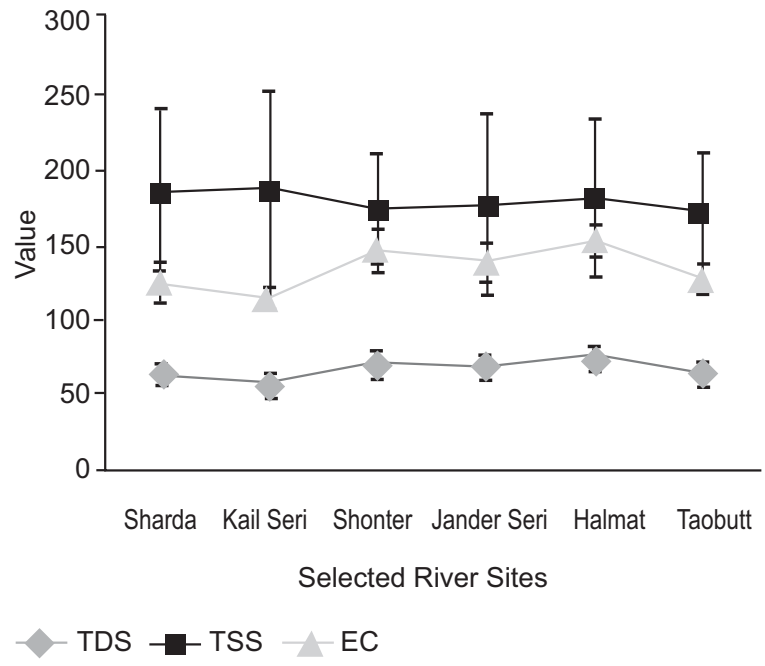

Fig. 2. Comparison of TSS, TDS and EC in selected sites of River Neelum in the study area during 2010-11. 
(Fig. 2). Turbidity ranged between $18.25 \pm 7.8 \mathrm{NTU}$ and $7.92 \pm 1.7 \mathrm{NTU}$ with the mean value of $12.01 \pm$ $1.70 \mathrm{NTU}$ (Table 1). Highest (18.25 $\pm 7.8 \mathrm{NTU}$ ) turbidity value was recorded at Sharda followed by Kail Seri $(16.03 \pm 4.6 \mathrm{NTU})$ and Shonter $(10.85+6.9 \mathrm{NTU})$, while lowest $(8.65 \pm 2.2 \mathrm{NTU})$ value was recorded at Jander Seri (Fig. 1). TDS value for River Neelum ranged between $57.50 \pm 4.7 \mathrm{mg} / \mathrm{L}$ and $75.83 \pm 5.0 \mathrm{mg} / \mathrm{L}$ with the mean value of $66.56 \pm 2.72 \mathrm{mg} / \mathrm{L}$ (Table 1). Highest TDS value was recorded at Halmat $(75.83 \pm 5.0 \mathrm{mg} / \mathrm{L})$, followed by Shonter $(71.33 \pm 7.6 \mathrm{mg} / \mathrm{L})$ and Jander Seri $(68.75 \pm 6.7 \mathrm{mg} / \mathrm{L})$. The minimum value was at Kail Seri $(57.5 \pm 4.70 \mathrm{mg} / \mathrm{L}$ (Fig. 2). TSS value ranged between $172.58 \pm 36.8 \mathrm{mg} / \mathrm{L}$ and $185.17 \pm 64.8 \mathrm{mg} / \mathrm{L}$, having a mean of $178.13 \pm 2.34 \mathrm{mg} / \mathrm{L}$ (Table 1). Maximum value $(185.17 \pm 64.8 \mathrm{mg} / \mathrm{L})$ was recorded at Kail Seri, followed by Sharda $(184.42 \pm 53.1 \mathrm{mg} / \mathrm{L})$ and Jander Seri $(175.33 \pm 60.4 \mathrm{mg} / \mathrm{L})$, with minimum value recorded at Shonter $(172.58 \pm 36.8 \mathrm{mg} / \mathrm{L})$ (Fig. 2). DO fluctuated between $8.18 \pm 1.4 \mathrm{mg} / \mathrm{L}$ and $9.09 \pm 0.5 \mathrm{mg} / \mathrm{L}$ with mean of $8.62 \pm 0.13 \mathrm{mg} / \mathrm{L}$ (Table 1). Highest value was noted at Jander Seri (9.09 $+0.5 \mathrm{mg} / \mathrm{L})$ followed by Halmat $(8.64 \pm 2.2 \mathrm{mg} / \mathrm{L})$, Shonter $(8.58 \pm 1.5 \mathrm{mg} / \mathrm{L})$, and Kail Seri $(8.18 \pm 1.4$ $\mathrm{mg} / \mathrm{L}$ ) (Fig. 1). Hardness of river water remained between $60 \mathrm{mg} / \mathrm{L}$ and $50 \mathrm{mg} / \mathrm{L}$ averaging at $54.50 \pm$ $1.5 \mathrm{mg} / \mathrm{L}$ (Table 2). Highest hardness $(60 \mathrm{mg} / \mathrm{L})$ recorded at Shonter, followed by $57 \mathrm{mg} / \mathrm{L}$ (Jander Seri), $55 \mathrm{mg} / \mathrm{L}$ (Taobutt), and $50.00 \mathrm{mg} / \mathrm{L}$ (Sharda) (Fig 3). Chloride range was $6 \mathrm{mg} / \mathrm{L}$ and $11 \mathrm{mg} / \mathrm{L}$ with mean value of $8.66 \pm 0.88 \mathrm{mg} / \mathrm{L}$. Highest $(11 \mathrm{mg} / \mathrm{L})$ value was recorded at Halmat followed by $10 \mathrm{mg} / \mathrm{L}$ (Shonther) and $9 \mathrm{mg} / \mathrm{L}$ (Jander Seri), while lowest $(6 \mathrm{mg} / \mathrm{L})$ value was recorded at Tao butt and Kail Seri sites (Fig 3). Selected sites of River Neelum showed $\mathrm{pH}$ range of $7.74 \pm 0.2$ and $7.24 \pm 1.6$ with mean value of $7.62 \pm$ 0.08 (Table 1). Highest value $7.74 \pm 0.2$ was at Sharda, followed by Jander Seri $(7.72 \pm 0.2)$ and Shonter $(7.68$ $\pm 0.20)$. Minimum $\mathrm{pH}$ value appeared at Kail Seri (7.24 +1.6) (Fig. 1). Nitrate concentration ranged between $3.39 \mathrm{mg} / \mathrm{L}$ to $5.52 \mathrm{mg} / \mathrm{L}$ with mean value of $4.55 \pm 0.3$ $\mathrm{mg} / \mathrm{L}$ in selected sites of River Neelum. Highest (5.52 $\mathrm{mg} / \mathrm{L}$ ) concentration was noted at Kail Seri followed by Taobutt $(5.21 \mathrm{mg} / \mathrm{L})$ and each at Sharda, Halmat, and Jander Seri $(4.40 \mathrm{mg} / \mathrm{L}$ each), whereas the minimum $(3.39 \mathrm{mg} / \mathrm{L})$ concentration was measured at Shonter (Fig 3). The nitrite concentration was ranged between $0.01 \mathrm{mg} / \mathrm{L}$ to $0.02 \mathrm{mg} / \mathrm{L}$ with the mean value of $0.01 \pm$ $0.005 \mathrm{mg} / \mathrm{L}$. Highest concentration of $0.02 \mathrm{mg} / \mathrm{L}$ was recorded at Jander Seri followed by Taobutt and Sharda $(0.01 \mathrm{mg} / \mathrm{L})$ whereas minimum $(0.01 \mathrm{mg} / \mathrm{L})$ concentration was noted at Kail Seri and Shonter (Fig 3). Sulphate was ranged from $6 \mathrm{mg} / \mathrm{L}$ to $75 \mathrm{mg} / \mathrm{L}$ with mean value of $40.16 \pm 11.0 \mathrm{mg} / \mathrm{L}$ in different sites of River Neelum. Maximum $(75 \mathrm{mg} / \mathrm{L})$ concentration was recorded at Kail Seri followed by Halmat and Taobutt $(60 \mathrm{mg} / \mathrm{L})$, while minimum $(6 \mathrm{mg} / \mathrm{L})$ concentration was measured at Jander Seri (Fig 3). COD ranged from $11 \mathrm{mg} / \mathrm{L}$ to $25 \mathrm{mg} / \mathrm{L}$ with the mean value of $16.66+1.9 \mathrm{mg} / \mathrm{L}$ (Table 2). Highest $(25.00 \mathrm{mg} / \mathrm{L})$ COD recorded at Taobutt followed by Shonter (18 mg/L) and Sharda (16 $\mathrm{mg} / \mathrm{L})$. Lowest $(11.00 \mathrm{mg} / \mathrm{L})$ value was measured at Jander Seri (Fig 3). BOD ranged between $5 \mathrm{mg} / \mathrm{L}$ and $13 \mathrm{mg} / \mathrm{L}$ with mean value of $9 \pm 1.09 \mathrm{mg} / \mathrm{L}$. Highest $(13 \mathrm{mg} / \mathrm{L})$ BOD recorded at Shonter followed by 10 $\mathrm{mg} / \mathrm{L}$ (Sharda and Taobutt) and $8 \mathrm{mg} / \mathrm{L}$ (Kail Seri and

Table 1. Descriptive statistical analysis of different physical parameters of River Neelum study area

\begin{tabular}{llllllll}
\hline \hline & Temperature $\left({ }^{\circ} \mathrm{C}\right)$ & $\mathrm{DO}(\mathrm{mg} / \mathrm{L})$ & $\mathrm{EC}(\mu \mathrm{S} / \mathrm{cm})$ & $\mathrm{TDS}(\mathrm{mg} / \mathrm{L})$ & $\mathrm{TSS}(\mathrm{mg} / \mathrm{L})$ & Turbidity $(\mathrm{NTU})$ & $\mathrm{pH}$ \\
\hline Mean & 7.34 & 8.62 & 132.53 & 66.57 & 178.13 & 12.01 & 7.62 \\
SE Mean & 0.08 & 0.13 & 5.91 & 2.72 & 2.34 & 1.70 & 0.08 \\
C.V. & 2.68 & 3.59 & 10.93 & 10.00 & 3.22 & 34.77 & 2.48 \\
Minimum & 7.08 & 8.18 & 112.75 & 57.50 & 172.17 & 7.92 & 7.24 \\
Maximum & 7.63 & 9.09 & 151.50 & 75.83 & 185.17 & 18.25 & 7.74 \\
\hline \hline
\end{tabular}

Table 2. Descriptive statistics of chemical parameters of River Neelum study area

\begin{tabular}{llllllllll}
\hline \hline & Alkalinity & BOD & COD & Chloride & Hardness & $\mathrm{NH}_{3}$ & Nitrate & Nitrite & $\mathrm{SO}_{4}$ \\
\hline Mean & 5.13 & 9.00 & 16.66 & 8.67 & 54.50 & 0.02 & 4.55 & 0.01 & 40 \\
SE Mean & 0.38 & 1.095 & 1.91 & 0.88 & 1.52 & 0.01 & 0.30 & 0.005 & 11 \\
Min. & 4.04 & 5.00 & 11.00 & 6.00 & 50.00 & 0.01 & 3.39 & 0.016 & 6 \\
Max. & 6.63 & 13.00 & 25.00 & 11.00 & 60.00 & 0.06 & 5.52 & 0.019 & 75 \\
\hline \hline
\end{tabular}


Halmat), lowest (5 mg/L) BOD recorded as at Jander Seri (Fig 3). Ammonia concen-tration in selected sites of River Neelum ranged from $0 \mathrm{mg} / \mathrm{L}$ to $0.06 \mathrm{mg} / \mathrm{L}$ with mean value of $0.01 \pm 0.001 \mathrm{mg} / \mathrm{L}$. Maximum $(0.06$ $\mathrm{mg} / \mathrm{L}$ ) ammonia concentration was measured at Halmat followed by Jander Seri $(0.04 \mathrm{mg} / \mathrm{L})$ and Taobutt $(0.02$ $\mathrm{mg} / \mathrm{L}$ ). No concentration was detected at Sharda, Kail Seri, Shonter and Taobutt (Fig 3). Alkalinity of the river water remained between $6.63 \mathrm{~mol} / \mathrm{L}$ and $4.04 \mathrm{~mol} / \mathrm{L}$ with mean of value of $5.13+0.93 \mathrm{~mol} / \mathrm{L}$ (Table 2). Highest $(6.63 \mathrm{~mol} / \mathrm{L})$ concentration recorded at Taobutt followed by $5.50 \mathrm{~mol} / \mathrm{L}$ (Jander Seri) and 5.46 $\mathrm{mol} / \mathrm{L}$ (Kail Seri). Lowest $(4.04 \mathrm{~mol} / \mathrm{L})$ value recorded at Shonter (Fig 3).

In selected river sites the maximum number of species were recorded at Saonar (8) followed by Sharda and Taobutt (7 each), Yamgar (6) and Sangli (5), whereas the minimum fish diversity was noted at Shonter (4) (Table 3). Temperature showed a highly significant $(\mathrm{p}<0.01)$ correlation with fish distribution in the River Neelum (Table 4).

The effects of physicochemical properties of water on fish diversity and distribution have been studied by various authors (Yadav and Rajesh, 2011; Aisien et al., 2010; Zwieniecki and Newton, 1999; Khan and Khan, 1997; Sinha and Banerjee, 1995; Beschta et al., 1987). Temperature is an important indicator of fish distribution hence it has considerable effects on fish distribution. In current study, temperature has highly significant $(p<0.01)$ correlation with fish diversity and its abundance

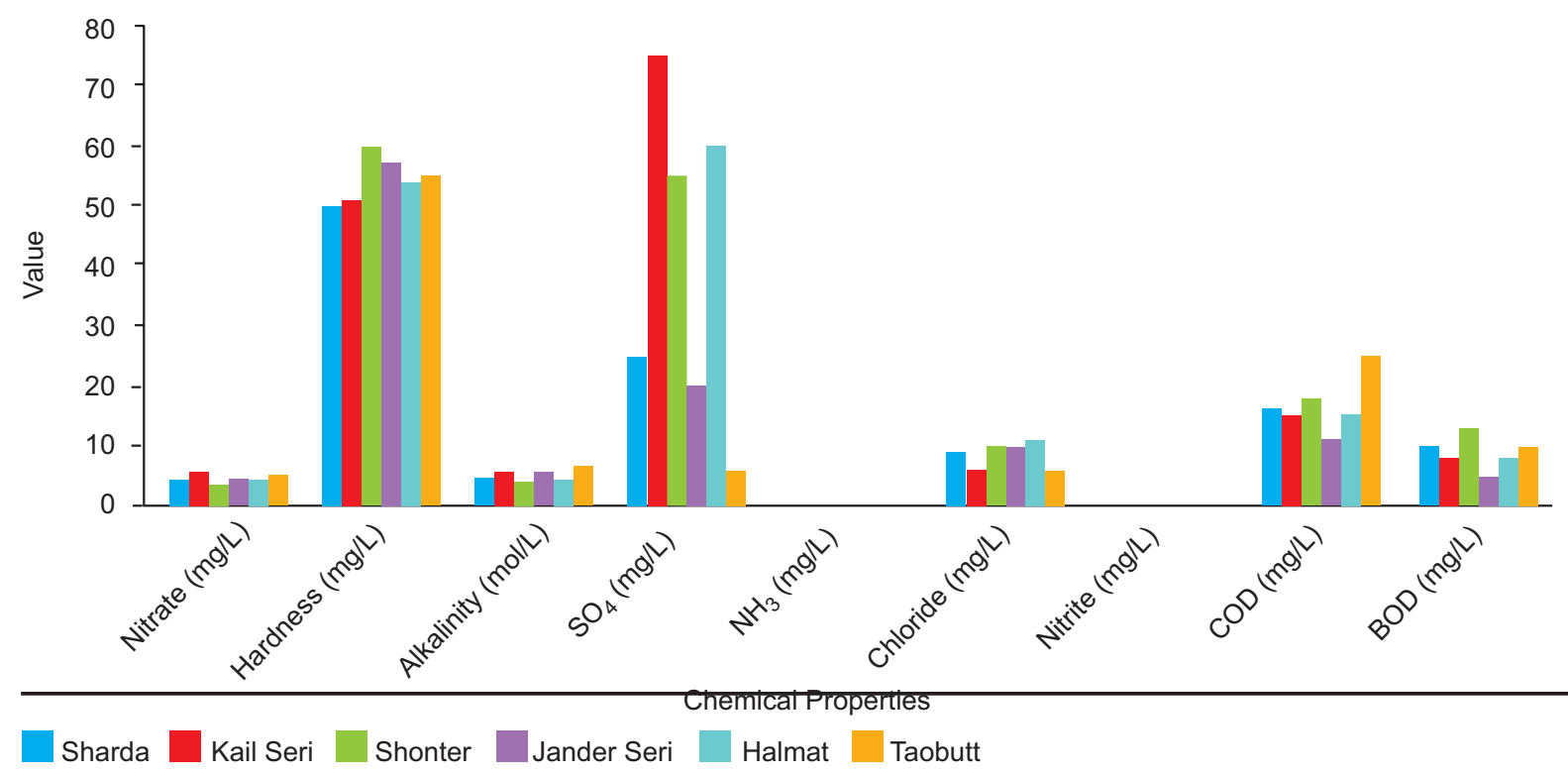

Fig. 3. Comparison of different chemical properties of selected sites of River Neelum in the study area during study period.

Table 3. Fish distribution in selected sites of River Neelum in the study area during 2010-11

\begin{tabular}{lllllll}
\hline \hline Species & Sharda & Kail Seri & Shonther & Yamgar & Saonar & Taobutt \\
\hline Oncorhynchus mykiss & + & + & + & + & + & + \\
Salmo trutta fario & + & - & + & - & + & + \\
Glyptothorax kashmirensis & + & - & - & + & + & - \\
Triplophysa stoliczkai & - & - & - & - & + & + \\
Diptychs maculatus & + & + & + & + & + & + \\
Schizothorax plagiostomus & + & + & + & + & + & + \\
Triplophysa kashmirensis & + & + & + & + & + & + \\
Glyptosternum reticulatum & + & + & + & + & + & + \\
Total Species & 7 & 5 & 4 & 6 & 8 & 7 \\
\hline \hline
\end{tabular}

+ Recorded, - Not recorded 
Table 4. Correlation among different water quality parameters of River Neelum during study period

\begin{tabular}{lll}
\hline \hline Parameter & R-Value & $\mathrm{p}$ Value \\
\hline Temperature & $0.93^{*}$ & 0.008 \\
EC & $0.67^{*}$ & 0.007 \\
TDS & $0.73^{*}$ & 0.002 \\
\hline \hline
\end{tabular}

* Highly significant $(\mathrm{p}<0.01)$

in River Neelum. Rise in temperature resulted in increase in the abundance of fish fauna in the river as also reported by Zwieniecki and Newton (1999) and Beschta et al. (1987). Mean temperature was recorded as 7.34 ${ }^{\circ} \mathrm{C}$ in present investigation which is favorable for survival of coldwater fishes as compared to regional water bodies, which have high temperatures such as River Ganga $\left(21^{\circ} \mathrm{C}\right.$ to $\left.22{ }^{\circ} \mathrm{C}\right)$ India (Sinha and Banerjee, 1995), Kabul $\left(20^{\circ} \mathrm{C}\right)$ (Khan and Khan, 1997), Koshi $\left(17.8^{\circ} \mathrm{C}\right)$ (Yadav and Rajesh, 2011) and Ethiope (25.5 $\left.{ }^{\circ} \mathrm{C}\right)$ (Aisien et al., 2010). Temperature values were in accordance to seasonal trend and may be attributed to area's altitudinal level (ranges from $1860 \mathrm{~m}$ asl to 2265 $\mathrm{m})$ as gradual decline was noted towards the lower altitude and considered as a main factor affecting fish distribution among sites.

Mean dissolved oxygen ranged between $8.26 \mathrm{mg} / \mathrm{L}$ to $8.90 \mathrm{mg} / \mathrm{L}$ in different water sources of the study area. Value could be compared with Ethiope River (6.85 $\mathrm{mg} / \mathrm{L}$ ) (Aisien et al., 2010), Kabul River (6.5 mg/L) (Khan and Khan, 1997) and Alaro River (6.27 mg/L) (Adedokun et al., 2008). Oxygen concentration indicated a low level of pollution in water of the study area. However, there was non-significant correlation of dissolved oxygen with fish distribution, as different sources have similar values for DO. Turbidity ranged between 10.85 NTU and 12.01 NTU at different sites of the study area. It increased gradually from Taobutt (upper site) to Sharda (lower site) showing a gradual addition of urban discharge and eroded soil. Some tributaries, particularly Shonter, laden by heavy girt enhanced turbidity of river water. Turbidity level in study area was higher than Ethiope River (4.20 NTU) (Aisien et al., 2010) and Alaro River (7.35 NTU) (Adedokun et al., 2008). Normal range of turbidity variations has no influence on fish rearing and distribution in study area, though elevated turbidity can decrease the feeding and growth rates of fishes (Mcleay et al., 1987; Sigler et al., 1984; Gardner, 1981). Mean $\mathrm{pH}$ range in different water sources of the study area was slightly basic (7.62 to 7.69), which was considered good for fish growth. $\mathrm{pH}$ of the surface water of study area is less than Ethiope River (5.1) (Aisien et al., 2010), and close to Koshi River (7.9), Kabul (7.4) and Alaro (7.59), respectively (Yadav and Rajesh, 2011; Adedokun et al., 2008; Khan and Khan, 1997).

Electrical conductivity has significant effects on fish distribution and is important indicator of water pollution. In present investigation, EC value was within the limit of WHO standards for surface water. Mean EC value ranged from $117.17 \mu \mathrm{S} / \mathrm{cm}$ to $132.53 \mu \mathrm{S} / \mathrm{cm}$ in different water sources of the study area, which could be comparable to the findings of Aisien et al. (2010) in Ethiope River $(801 \mu \mathrm{S} / \mathrm{cm})$ and (Khan and Khan, 1997) in Kabul River $(263 \mu \mathrm{S} / \mathrm{cm})$. TDS value is in permissible limit of WHO for surface water. Mean value of total suspended solids was ranging from $177.64 \mathrm{mg} / \mathrm{L}$ to $180.79 \mathrm{mg} / \mathrm{L}$ in the water sources of the study area which is slightly greater than Ethiope River $(110 \mathrm{mg} / \mathrm{L})$ (Aisien et al., 2010) and less that in Nayal River (302 $\mathrm{mg} / \mathrm{L}$ ) (Nair et al., 2005). Value of TSS in current study was found according to WHO limit for surface water sources, however a non significant correlation was found between fish distribution and TSS value of the study area. Mean value for hardness ranging from 54.50 $\mathrm{mg} / \mathrm{L}$ to $59.67 \mathrm{mg} / \mathrm{L}$ showing no environmental burden in the study area, however non-significant correlation was noted between fish distribution. Other studies showed higher value of hardness as compared to the study area including Alaro River (102 mg/L) (Adedokun et al., 2008), Gallikos River (360 mg/L) (Mattas et al., 2005) and Huluka (200 mg/L) (Awulachew et al., 2007). Hardness of water sources of study area is according to WHO limit for this parameter for surface water. Mean alkalinity value ranged between $6.18 \mathrm{~mol} / \mathrm{L}$ and 6.85 mol/L found according to WHO parametric limit and it is less than the value of Kabul $(119 \mathrm{~mol} / \mathrm{L})(\mathrm{Khan}$ and Khan, 1997) and Alaro River (111.73 mol/L) (Adedokun et al., 2008), however non-significant effects were noted on fish distribution.

Mean BOD value ranged from $9.00 \mathrm{mg} / \mathrm{L}$ to $10.13 \mathrm{mg} / \mathrm{L}$ in study area. These values are higher as compared to the finding of Aisien et al. (2010), Yadav and Rajesh (2011) and Khan and Khan (1997) in Ethiope (6.85 $\mathrm{mg} / \mathrm{L})$, Koshi (12.7 mg/L) and Kabul ( $0.8 \mathrm{mg} / \mathrm{L})$ rivers, respectively. BOD has non-significant effects on fish distribution in current study. Mean COD value ranged from $16.13 \mathrm{mg} / \mathrm{L}$ to $16.16 \mathrm{mg} / \mathrm{L}$ which is comparatively higher than BOD value, while non-significant correlation 
was noted between fish distribution and COD. Results could be compared with COD concentration in Ethiope River (6.05 mg/L) (Aisien et al., 2010) Koshi (11.4 mg/L) (Yadav and Rajesh, 2011) and Kabul River (23.0 mg/L) measured by Khan and Khan (1997).

Chloride concentration remained below permissible limit of WHO for surface water. Its mean concentration ranged from $8.66 \mathrm{mg} / \mathrm{L}$ to $9.13 \mathrm{mg} / \mathrm{L}$ in various water sources of the study area. This indicated no pollution burden in surface water of the study area, however nonsignificant correlation was noted between chloride concentration and fish distribution in the study area. These findings could be compared with earlier studies such as Yadav and Rajesh ( 2011) that is $24 \mathrm{mg} / \mathrm{L}$ in Koshi River, Khan and Khan (1997) in Kabul (7 mg/L) and Adedokun et al. (2008) in Alaro River.

Ammonia was almost negligible in surface water of the study area. Mean concentration ranged between 0.01 $\mathrm{mg} / \mathrm{L}$ to $0.02 \mathrm{mg} / \mathrm{L}$ indicating decreased pollution in water source of Neelum. As compared with other studies, no ammonia concentration recorded by Khan and Khan (1997) and Aisien et al. (2010); in Kabul and Ethiope Rivers, respectively, however non-significant correlation was noted with fish distribution in the study area. Mean nitrate concentration ranged from $4.36 \mathrm{mg} / \mathrm{L}$ to 6.03 $\mathrm{mg} / \mathrm{L}$ in different water sources of study area. Nonsignificant correlation was noted between fish distribution and nitrate. Nitrate concentration remained according to WHO limit. Nitrite concentration was negligible in different water sources, it ranged from 0.010 to $0.012 \mathrm{mg} / \mathrm{L}$ showing non-significant effects on fish distribution. Decreased nitrite values are due to lesser agricultural practice in the area. Similar results showed by Khan and Khan (1997) for Kabul River and Yadav and Rajesh (2011) in Koshi River, India. The mean value of sulphate concentration in various surface water sources in current study ranged from $33.0 \mathrm{mg} / \mathrm{L}$ to $40.16 \mathrm{mg} / \mathrm{L}$ falling in permissible limit of WHO standard for surface water. Sulphate has non-significant effects on fish distribution. Value could be compared with the findings of Aisien et al. (2010) in Ethiope River (5.28 mg/L), Khan and Khan (1997) in Kabul (26 mg/L) and Mattas et al. (2005) in Gallikos River $(45.0 \mathrm{mg} / \mathrm{L})$. There were a total of 8 species including Oncorhynchus mykiss, Salmo trutta fario, Glyptothorax kashmirensis, Triplophysa stoliczkai, Diptychs maculatus, Schizothorax plagiostomus, Triplophysa kashmirensis and Glyptosternum reticulatum recorded in study area. Maximum species were recorded at Sonar
River sites while minimum species were noted at Shonter. Temperature showed a highly significant $(\mathrm{p}<0.01)$ correlation with fish distribution in River Neelum. Fish diversity varied in different study sites.

The results are in accordance to our current understanding that AJ\&K is least polluted area. This area is characterized by relatively stable physicochemical features that result in stable aquatic ecosystem. However, this scenario may not persist further in feuature as India has started the construction of several dams on this river in Occupied Kashmir. After their completion, water flow will decrease, resulting in the concentration of pollutant that may exceed WHO guidelines. This baseline study can be used as a reference for future exploration.

\section{Acknowledgement}

Authors are grateful to Prof. Dr. Afsar Mian for helping in designing this study. We thank to Mr. Javaid Ayub Director, Wildlife and Fisheries Azad Jammu \& Kashmir, for granting permission to capture fish specimens from Neelum River and helping in field tours. We are indebted to Kafayat Naqvi and Imran Mughal (Makri Water Testing Laboratory, Public Health Department, Government of AJ\&K, Muzaffarabad) for providing portable water testing meters and performing some of laboratory analysis of collected water samples.

Conflict of Interest. The authors declare no conflict of interest

\section{References}

Adedokun, O.A., Adeyemo, O.K., Adeleye, E., Yusuf, R.K. 2008. Seasonal limnological variation and nutrient load of the river system in Ibadan metropolis, Nigeria. European Journal of Scientific Research, 23: 98-108.

Aisien, E.T., Gbegbaje, G.D., Aisi, F.A. 2010. Water quality assessment of river Ethiope in the Nigerdelta coast of Nigeria. Electronic Journal of Environmental, Agricultural and Food Chemistry, 9: 1739-1745.

Akhtar, N. 1991. Azad Jammu \& Kashmir. Fisheries profile, feasible sites for trout culture and an overall sectoral development perspective. Report for Project PAK/88/084. FAO, Rome, pp 25.

Ali, M., Hussain, S., Mahmood, J. A., Iqbal, R. and Farooq, A. 2010. Fish Diversity of Fresh Water 
Bodies of Suleman Mountain Range, Dera Ghazi Khan Region, Pakistan. Pakistan Journal of Zoology, 42: $285-289$.

Ali, S.R., Ahmad, M., Ansari, M.A.S., Mirza, M.R. 1980. Hydrobiological studies of the Indus River and its tributaries above and below Tarbela Dam. Pakistan Journal of Scientific Studies, 2: 15-30.

Ali, U. 2010. Assessment of drinking water quality of Muzaffarabad, Azad Kashmir. M. Phil Dissertation, Department of Environmental Sciences PMASArid Agriculture University, Rawalpindi, pp 70.

Ali, U., Ahmed, K., Awan, M.S., Ashrif, S., Khan, B., Awan, M. N. 2007. Distribution and population estimation of Himalayan Ibex (Capra ibex sibirica) in upper Neelum valley, district Neelum Azad Kashmir. Pakistan Journal of Biological Science, 10: 3150-3153.

APHA, 2005. Standard Methods for the Examination of Water and Wastewater, 1193 pp. $21^{\text {st }}$ edition, American Public Health Association, Washington, USA.

Awulachew, S.B., Yilma, A.D., Loulseged, M., Loiskandl, W., Ayana, M., Alamirew, T. 2007. Water Resources and Irrigation Development in Ethiopia", International Water Management Institute, Colombo, Sri Lanka. Working Paper 123.

Barrett, J.D., Grossman, G.D., Rosenfeld, J. 1992. Turbidity-induced changes in reactive distance in rainbow trout. Transactions of the American Fisheries Society, 121: 437-443.

Benfield, M.C., Minello, T.J. 1996. Relative effects of turbidity and light intensity on reactive distance and feeding of an estuarine fish. Environmental Biology of Fishes, 46: 211-216.

Beschta, R.L., Bilby, R.E., Brown, G.W., Holtby, L.B., Hofstra, T.D. 1987. Stream temperature and aquatic habitat: fisheries and forestry interactions. In Streamside Management: Forestry and Fishery Interactions, Salo, E. O. and Cundy, T. W. (eds). pp. 191-232, Institute of Forest Resources, University of Washington, Seattle, WA, USA.

Cloramm, A. 2010. Physic-chemical characteristics of Pennar River, A Fresh under wetland in Kerala, India. E-Journal of Chemistry, 7: 1266-1273.

Cussac, V.E., Ferna, D.A., Mez, E.G., Lopez, H.L. 2009.

Fishes of southern South America: a story driven by temperature. Journal of Fish Physiology and Biochemistry, 35: 29-42.

Emara, H.I., El- Deek, M.S., Ahmed, N.S. 1993. Comparative study on the levels of trace metals in some Mediterranean and Fresh water fishes. Chemistry and Ecology, 8: 119-127.

Gardner, M.B. 1981. Effects of turbidity on feeding rates and selectivity of bluegills. Transactions of the American Fisheries Society, 110: 451-454.

Gasim, M.B., Toriman, M.E., Rahim, S.A., Islam, M.S., Che, T.C., Jauhir, H. 2006. Hydrology, water quality and land-use assessment of Tasik Chini's feeder rivers, Pahang Malaysia. Geografia- Malaysian Journal of Society and Space, 2: 72-86.

Gorman, O.T., Karr, J.R. 1978. Habitat structure and stream fish communities. Ecology, 59: 507-515.

Grenouillet, G., Pont, D., Seip, K. L. 2002. Abundance and species richness as a function of food resources and vegetation structure: juvenile fish assemblages in rivers. Ecography, 25: 641-650.

Kamal, D., Khan, A.N., Rahman, M.A., Ahmed, F. 2007. Biochemical composition of some small indigenous fresh water fishes from the River Mouri, Khulna, Bangladesh. Pakistan Journal of Biological Science, 10: 1559-1561.

Khan, S.A., Khan, M. 1997. Monitoring of water pollution in the Kabul River (Pakistan) under low flow conditions. Journal of the Chemical Society of Pakistan, 19: 126-132.

Maitland, P. S. 2004. Evaluating the ecological and conservation status of freshwater fish communities in the United Kingdom. Scottish Natural Heritage Commissioned Report,1: 1-94.

Mattas, C., Soulios, G., Dimopoulos, G., Diamantis, J., Panagopoulos, A., Voudouris, K. 2005. Groundwater quality in Gallikos basin, Prefecture of Kilkis, G. Stournaras (ed.), Proceeding. of $7^{\text {th }}$ Hellenic Conference on Hydrogeology Athens: 311-320.

McLeay, D.J., Birtwell, I.K., Hartman, G.F., Ennis, G. L. 1987. Responses of Arctic grayling, Thymallus articus, to acute prolonged exposure to Yukon placer mining sediment. Canadian Journal of Fisheries and Aquatic Sciences, 44: 658-673

Mendonca, F.P., Magnusson, W.E., Zuanon, J. 2005. Relationships between Habitat Characteristics and Fish Assemblages in Small Streams of Central Amazonia. Copeia, 2005 4: 751-764.

Mirza, M.R. 1982. A Contribution to the Fishes of Lahore, 75 pp. $1^{\text {st }}$ edition, Polymer Publishers, Urdu Baazar Lahore, Pakistan.

Miserendino, M.L., Brand, C., Di Prinzio, C.Y. 2008. Assessing urban impacts on water quality, benthic communities and fish in streams of the Andes 
Mountains, Patagonia (Argentina). Water, Air, and Soil Pollution, 194: 91-110.

Nair, A., Abdullah, G., Mahamoud, I. M. 2005. Physiochemical parameters and correlation coefficients of ground waters of North-East Libya. Journal of Pollution Research, 24:1- 6.

Qamar, Z.Q., Anwar, M., Dar, N.I., Ali, U. 2010. Ethnobotanical study of wild medicinal plants of Neelum Valley, Azad Jammu and Kashmir, Pakistan. Pakistan Journal of Wildlife, 1: 25-30.

Rauf, A., Javed, M., Ubaidullah, M. 2009. Heavy metal levels in three major carps (Catla catla, Labeo rohita and Cirrhina mrigala) from the River Ravi, Pakistan. Pakistan Veterinary Journal, 29: 24-26.

Rivas, L.R. 1958. The origin, evolution, dispersal, and geographical distribution of the Cuban Poeciliid Fishes of the Tribe Girardinini. Proceedings of the American Philosophical Society, 102: 281-320.

Sarkar, U.K., Pathak, A.K., Lakra, W.S. 2008. Conservation of freshwater fish resources of India: New approaches, assessment and challenges. Biodiversity and Conservation, 17: 2495-2511.

Siddiqui, P.J.A., Farooq, S., Shafique, S., Burhan, Z. N., Farooqi, Z. 2008. Conservation and management of biodiversity in Pakistan through the establishment of marine protected areas. Ocean \& Coastal
Management, 51: 377-382.

Sigler, J.W., Bjorn, T.C., Everest. F. H. 1984. Effects of chronic turbidity on density and growth of Steelheads and Coho salmon. Transactions of the American Fisheries Society, 113:142-150.

Sinha, S.N., Banerjee, R.D. 1995. Pollution indicators and impact assessment of pollutants discharged into the river Ganga. International Journal of Environmental Studies, 48: 231- 244.

Taniguchi, Y., Nakano, S. 2000. Condition-specific competition: Implications for the altitudinal distribution of stream fishes. Ecology, 81: 20272039.

Torgersen, C.E., Faux, R.N., McIntosh, B.A., Poage, N. J., Norton, D. J. 2001. Airborne thermal remote sensing for water temperature assessment in rivers and streams. Remote Sensing of Environment, 76: 386-398.

Yadav, S.S., Rajesh, K. 2011. Monitoring Water quality of Kosi River in Rampur District, Uttar Pradesh, India. Advances in Applied Science Research, 2: 197-201.

Zwieniecki, M., Newton, M. 1999. Influence of streamside cover and stream features on temperature trends in forested streams of Western Oregon. Western Journal of Applied Forestry, 14: 106-112. 